\title{
CONSIDERATIONS ON THE IMPACT OF ONLINE EDUCATION ON ACADEMIC PERFORMANCE - AN ASSESSMENT OF THE EFFECTS OF COVID 19 CONFINEMENT-
}

\author{
Cristina Vilaplana Prieto \\ University of Murcia (SPAIN), cvilaplana@um.es
}

\begin{abstract}
Given the current panorama of secondary and higher education imposed by the COVID-19, in which face-toface and non face-to-face classes have to be combined, the question arises as to how this teaching methodology can affect the acquisition of the necessary skills. It is still too early to have data that would allow a comparison of the situation before the confinement with the current one. However, the implementation of the use of computers as a learning tool in some Autonomous Communities in previous courses allows a tentative estimate of what these effects will be.

The aim of this paper is to analyse the contribution of the Program School 2.0 to the skill-building in the subject of Mathematics. Between 2009 and 2010, all Autonomous Communities (except Madrid, Murcia and Comunidad Valenciana) participated in this program which pursued the objective of providing individual computer equipment and computer assisted learning to all students in $5^{\circ}-6^{\circ}$ grade of Primary Education and $1^{\circ}-2^{\circ}$ grade of Secondary Education. The availability of PISA 2012 allows the comparison with previous results of PISA 2009, and thus, to contrast the utility of this program. For this purpose, we have estimated a "difference in difference" model for Mathematics score in the general module and in the "computer based assessment (CBA)" module. Results show that for non-repeaters students, the availability of notebook or tablet decreases the score in Mathematics-CBA (-48.35 for participants Communities, -23.26 for nonparticipants). Non-repeaters students who used the computer for doing their homework 1-2 times per week have experienced a decrease in participant Communities (-3.15), but an increase in non-participant Communities (55.62). However, we cannot discard the existence of positive externalities because students of participant Communities are more prone to help each other with Mathematics as compared to nonparticipants students.
\end{abstract}

Keywords: ICT, computer assisted learning, Mathematics, PISA.

\section{INTRODUCTION}

The analysis of the implementation of ICT in schools and high schools has sparked debate and controversy during the last decade. An abundant literature has emerged, but there are no concluding results. Some studies have appreciated a substantial improvement of students' achievement as a result of the introduction of ICT as a new educational methodology. For example, [1] analyzed the effect of the increase in computerstudent ratio in schools of United Kingdom between 1999-003. They used an instrumental variables approach to control for a potential endogeneity problem of the use of ICT, and concluded that the increase in computer investment had improved academic results in Elementary education. Other studies have analyzed the effect of ICT over repeater students or student with lower achievement. [2] measured the effect of ICT over students of Indian slums and observed an increase in Mathematic scores, but no significant effects over 
other subjects. In the same line, [3] in United States and [4] in Canada obtained positive influence of ICT over academic results.

However other studies have not concluded that there is a significant relationship between the use of ICT at schools and educational achievement. [5] concluded that a program implemented in United States, which consisted in the provision of financial support to schools with the purpose of increasing the number of computer per student and improving internet access, had not had any significant effect over students' achievement. Other authors have ascertained that the introduction of ICT has undermined academic result. [6] compared the educational achievement of primary schools and high schools in Israel, using as differential variable the participation in a state-funded-program to increase the number of computers in the classrooms. They observed a negative effect of ICT and Mathematics scores for $4^{\text {th }}$ grade students. In the same line, [7] concluded that the allocation of funds to improve computer-student ratio in Dutch schools had led to worse Language and Mathematics results.

Several theoretical and empirical explanations have been proposed to explain the divergence of results. On one hand, ICT may be considered as an additional "input" in the student's learning function, because the student can obtain more information and access more easily to learning resources at school and at home (and at any moment). On the other hand, the benefits derived of ICT are conditioned by ability of the centers to modify their teaching methods, so that teachers and ICT become complementary. We should avoid what is known as "productivity paradox" [8] that is, that insufficient organizational or educational changes weight down the potential benefits of ICT.

In July 2009, the Spanish Ministry of Education approved the development of the Program School 2.0 with an investment of $98,142,419 €$ (Resolución de 3 de agosto de 2009, de la Secretaría General Técnica, por la que se publica el Acuerdo del Consejo de Ministros de 31 de julio de 2009). The objectives of this program were: i) provide each student with notebook or digital pad, ii) transform all classrooms in digital classrooms, and iii) provide the necessary instruction to teachers. The program was implemented in $5^{\text {th }}$ and $6^{\text {th }}$ grade of Elementary Education and $1^{\text {st }}$ and $2^{\text {nd }}$ grade of High School, but only in public centers. All Autonomous Communities with the exception of Madrid, Murcia and Comunidad Valenciana participated in this program. The availability of the results of PISA 2012 offers us to determine the impact of the program School 2.0 in Mathematic achievement of students.

\section{DATA, SAMPLE DESIGN AND ECONOMETRIC MODEL}

Data used come from PISA survey (Program for International Student Assessment) carried out by the OECD every three years to assess the competencies of 15-year-old students in reading, mathematics and science. The $5^{\text {th }}$ edition for 2012 has been focused on Mathematics achievement. In this paper we concentrate on students with level ISCED-2A studying in public centers. The exclusion of private and state subsidized centers is due to the fact that the program School 2.0 was only implemented in public schools. We have a sample of 15,430 observations for the general module of PISA 2012 and 5,595 observations for module of "Computer Based Assessment". This specific module consisted in solving tasks that were administered computer-based and was only performed in a subsample of PISA respondents.

As the objective of the paper is the determination of the success level of the program School 2.0 we need to compare Mathematic scores in 2009 and in 2012 to evaluate to which extend this program has contributed to the change in Mathematics performance. For this purpose, we incorporate in our analysis 11.049 observations of PISA 2009 (as before, 15-year-old students with level ISCED-2A studying in public centers) and 1,462 observations of PISA-ERA (Electronic Reading Assessment). To determine if the program School 2.0 has had a different influence over Mathematics achievement using pen-and-paper formats or using computers, we will compare the results of the general modules of PISA 2009 with PISA 2012 and also PISAERA2009 with PISA-CBA 2012

Regarding the analytical framework, we propose to estimate a "difference-in-difference" model. This model allows us to catch the effect of the participation in School 2.0 over Mathematics achievement. The dependent variable is the Mathematics score of student $i$ belonging to school $j\left(\right.$ Math $\left._{\mathrm{i} j \mathrm{j}}\right)$ :

Math $_{\mathrm{i} j}=\alpha_{0}+\alpha_{1} X_{\mathrm{i}}+\alpha_{2} X_{j}+\alpha_{\mathrm{a}}$ Year $_{2012}+\alpha_{4}$ Part $_{j}+\alpha_{\mathrm{a}}$ Year $_{2012} \cdot$ Part $_{j}+\varepsilon_{\mathrm{i}}+\mu_{j}+v_{\mathrm{ij}}$

where $X_{\mathrm{i}}$ refers to observable characteristics of the student and his/her family, $X_{j}$ refers to characteristics of the school, Part $_{j}$ is a binary variable that takes the value 1 if the Community has participated in the program 
School 2.0, Year $_{2012}$ is a binary variable that takes the value 1 in 2012, 2012, Year $_{2012} \cdot$ Part $_{j}$ is a binary variable for the interaction between participation in School 2.0 and year 2012, $\varepsilon_{i}$ denotes unobservable student characteristics, $\mu_{j}$ denotes unobservable characteristics of the school, and finally, $v_{i j}$ is a random error term. PISA gives 5 plausible values for the Mathematics score of each student. For the estimation of the model, we have followed the methodology proposed by [9].

\section{RESULTS}

Table 1 shows Mathematics score in PISA 2009 and PISA 2012 according to the level of participation of the Autonomous Community in the program School 2.0. We distinguish three levels of participation: (i) Fully participant Communities, where all schools were adapted to computers based learning (Andalucía, Aragón, Cantabria, Cataluña, Castilla León, Castilla La Mancha, Ceuta and Melilla, Extremadura, Galicia, Navarra, Rioja, País Vasco),

(ii) Partial-participant Communities, where only a certain fraction of schools were adapted to computer based learning (Asturias, Baleares and Canarias)

(iii) Non-participant Communities which did not took part in the program School 2.0 (Madrid, Murcia and Comunidad Valenciana).

However, non-participation in the program does not prevent neither the introduction of ICT in the schools, nor the resource ICT as part of student's homework. It depends of the will and competence of the school/high-school. We also differentiate Mathematics scores according to the level of grade repetition: $\operatorname{REP}(0)$ for non-repeater students, $\operatorname{REP}(1,0)$ if they have repeated one year of Elementary Education: $\operatorname{REP}(0,1)$ if they have repeated one year of High School; $\operatorname{REP}(1,1)$ if they have repeated one year of Elementary Education and another of High School, $\operatorname{REP}(0,2)$ if they have repeated two years of High School.

In 2009, Mathematics score for those Communities which afterwards participated in the program School 2.0 was higher than the average score for Communities which did not became participants, for all the students and 1-year repeater students. In 2012, we appreciate the same result for all the students, for $\operatorname{REP}(1.0)$, and also for $\operatorname{REP}(0,2)$.

On the other hand, non-participant Communities showed a higher Mathematics score as compared to partialparticipant Communities for all students, no repeaters and 1-year repeater students. In 2012, we observe the same result.

Table 1. Mean and standard deviations of Mathematics scores for public schools

\begin{tabular}{|c|c|c|c|c|c|c|c|}
\hline & & \multicolumn{3}{|c|}{ Has participated in School 2.0? } & \multicolumn{3}{|c|}{ Test for equal means } \\
\hline & & No & $\begin{array}{l}\text { Yes, } \\
\text { totally }\end{array}$ & $\begin{array}{c}\text { Yes, } \\
\text { partially }\end{array}$ & $\begin{array}{c}\text { No vs. } \\
\text { Yes }\end{array}$ & $\begin{array}{c}\text { No. Vs. Yes } \\
\text { (partially) }\end{array}$ & $\begin{array}{c}\text { Yes vs. Yes } \\
\text { (partially) }\end{array}$ \\
\hline \multicolumn{8}{|c|}{ PISA 2012. Mathematics scores for general module } \\
\hline Total & $\begin{array}{l}\text { Mean } \\
\text { Std. Dev } \\
N\end{array}$ & $\begin{array}{c}470.92 \\
88.58 \\
2230\end{array}$ & $\begin{array}{c}477.24 \\
86.33 \\
11066\end{array}$ & $\begin{array}{c}446.01 \\
83.51 \\
2134\end{array}$ & 0.0001 & 0.0000 & 0.0000 \\
\hline $\operatorname{REP}(0,0)$ & $\begin{array}{l}\text { Mean } \\
\text { Std. Dev } \\
\text { N }\end{array}$ & $\begin{array}{c}512.16 \\
75.83 \\
1353\end{array}$ & $\begin{array}{c}510.46 \\
76.42 \\
7468\end{array}$ & $\begin{array}{c}490.42 \\
74.28 \\
1400\end{array}$ & 0.3584 & 0.0000 & 0.0000 \\
\hline $\operatorname{REP}(0,1)$ & $\begin{array}{l}\text { Mean } \\
\text { Std. Dev } \\
N\end{array}$ & $\begin{array}{c}437.63 \\
65.95 \\
473\end{array}$ & $\begin{array}{c}433.43 \\
63.45 \\
2074\end{array}$ & $\begin{array}{c}410.76 \\
61.79 \\
356\end{array}$ & 0.1210 & 0.0000 & 0.0000 \\
\hline $\operatorname{REP}(1,0)$ & $\begin{array}{l}\text { Mean } \\
\text { Std. Dev } \\
N\end{array}$ & $\begin{array}{c}391.34 \\
68.40 \\
135\end{array}$ & $\begin{array}{c}405.02 \\
65.54 \\
595\end{array}$ & $\begin{array}{c}403.55 \\
51.48 \\
181\end{array}$ & 0.0153 & 0.0730 & 0.7729 \\
\hline $\operatorname{REP}(1,1)$ & $\begin{array}{l}\text { Mean } \\
\text { Std. Dev } \\
\text { N }\end{array}$ & $\begin{array}{c}379.14 \\
67.19 \\
194\end{array}$ & $\begin{array}{c}376.89 \\
63.11 \\
676\end{array}$ & $\begin{array}{c}365.08 \\
64.30 \\
153\end{array}$ & 0.6257 & 0.0619 & 0.0285 \\
\hline $\operatorname{REP}(0,2)$ & $\begin{array}{l}\text { Mean } \\
\text { Std. Dev } \\
N\end{array}$ & $\begin{array}{c}385.72 \\
61.05 \\
65\end{array}$ & $\begin{array}{c}412.11 \\
60.99 \\
218\end{array}$ & $\begin{array}{c}397.59 \\
54.23 \\
34\end{array}$ & 0.0004 & 0.4476 & 0.2072 \\
\hline \multicolumn{8}{|c|}{ PISA 2009. Mathematics scores for general module } \\
\hline Total & $\begin{array}{l}\text { Mean } \\
\text { Std. Dev }\end{array}$ & $\begin{array}{c}456.11 \\
88.55\end{array}$ & $\begin{array}{c}467.39 \\
87.59\end{array}$ & $\begin{array}{l}471.08 \\
85.97\end{array}$ & 0.0000 & 0.0000 & 0.0925 \\
\hline
\end{tabular}


Proceedings of INTCESS 2021 8th International Conference on Education and Education of Social Sciences 18-19 January, 2021

\begin{tabular}{|l|l|c|c|c|c|c|c|} 
& N & 1571 & 7242 & 2236 & & \\
& Mean $(0,0)$ & 510.06 & 513.65 & 517.49 & 0.1586 & $\mathbf{0 . 0 1 0 5}$ & 0.0943 \\
& Std. Dev & 70.58 & 72.20 & 69.24 & & & \\
REP-1 year & $\mathrm{N}$ & 927 & 4452 & 1415 & & & \\
& Mean & 417.66 & 427.78 & 435.85 & $\mathbf{0 . 0 0 2 0}$ & $\mathbf{0 . 0 0 0 0}$ & $\mathbf{0 . 0 1 1 0}$ \\
& Std. Dev & 69.81 & 69.53 & 69.36 & & & \\
REP-2 yers & $\mathrm{N}$ & 520 & 2305 & 660 & & & 0.2845 \\
& Mean & 362.91 & 362.25 & 369.15 & 0.9235 & 0.4403 & \\
& Std. Dev & 70.74 & 74.63 & 65.62 & & & \\
& $\mathrm{~N}$ & 124 & 485 & 161 & & & \\
\hline
\end{tabular}

Source: Own work using PISA (2009) and PISA (2012). Using sample weights

Fig. 1 to 3 show the relationship between Mathematics score in PISA 2009 and its growth rate between 2009 and 2012 by Autonomous Communities ${ }^{1}$ and number of repeated grades. We appreciate a negative evolution between 2009 and 2012 for both repeater and non-repeater students (negative slope of the regression lines for the three figures). Communities who attained the best results in PISA 2009 have experience the most acute decrease in Mathematics score. The highest slope of the regression line corresponds to 1 -year repeater students.

We also appreciate a rather different evolution among Communities. For example, Castilla-León attained the lowest score for non-repeater students in PISA 2009, but it has achieved the highest increase between 2009 and 2012. By the contrary, Ceuta and Melilla obtained a medium level score, but they have suffered a serious step back between 2009 and 2012.

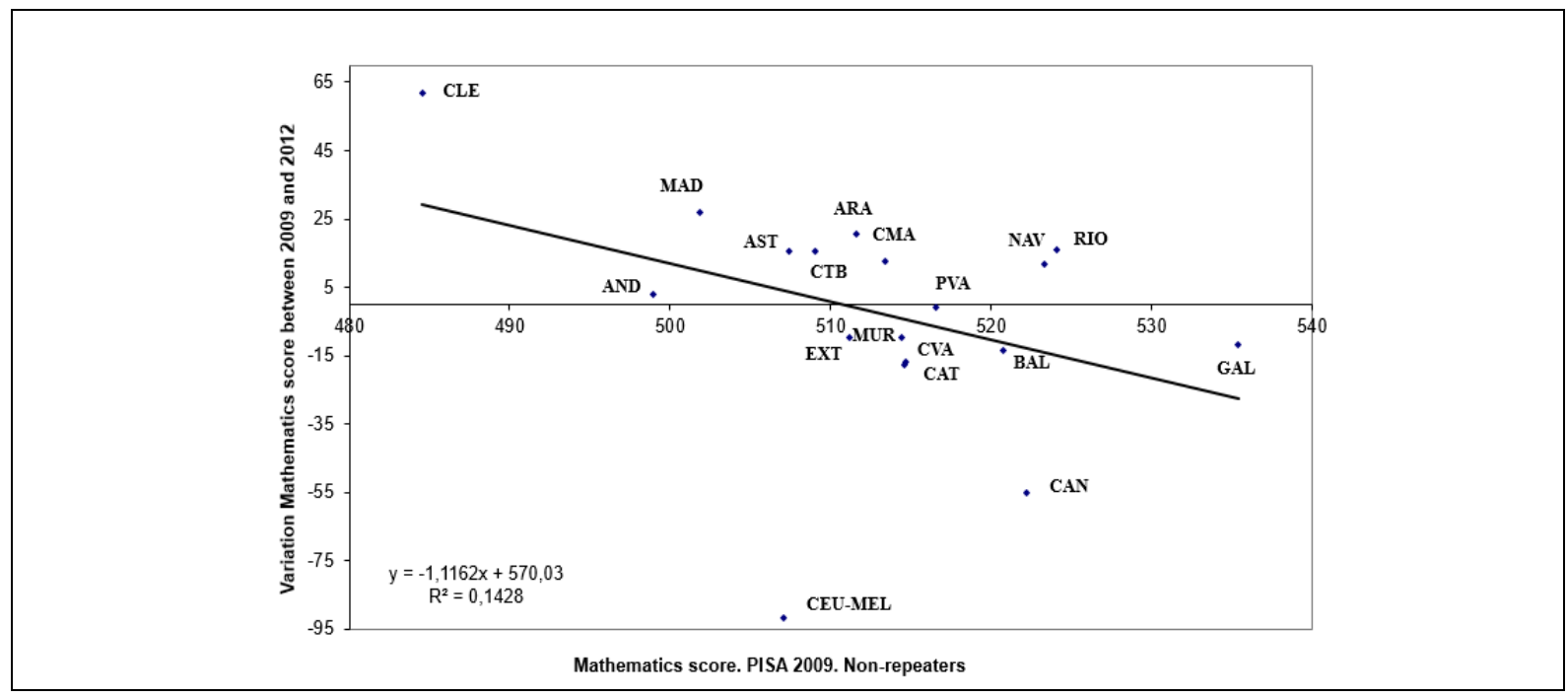

${ }^{1}$ In the graphs we have used the following abbreviation: AND: Andalucía; ARA: Aragón; AST: Asturias; BAL: Baleares; CAN: Canarias; CAT: Cataluña; CLE: Castilla-León; CMA: Castilla La Mancha; CTB: Cantabria: CVA: Comunidad Valenciana; CEU MEL: Ceuta and Melilla; EXT: Extremadura; GAL: Galicia: MAD: Madrid; MUR: Murcia, NAV: Navarra; RIO: Rioja; PVA: País Vasco. 


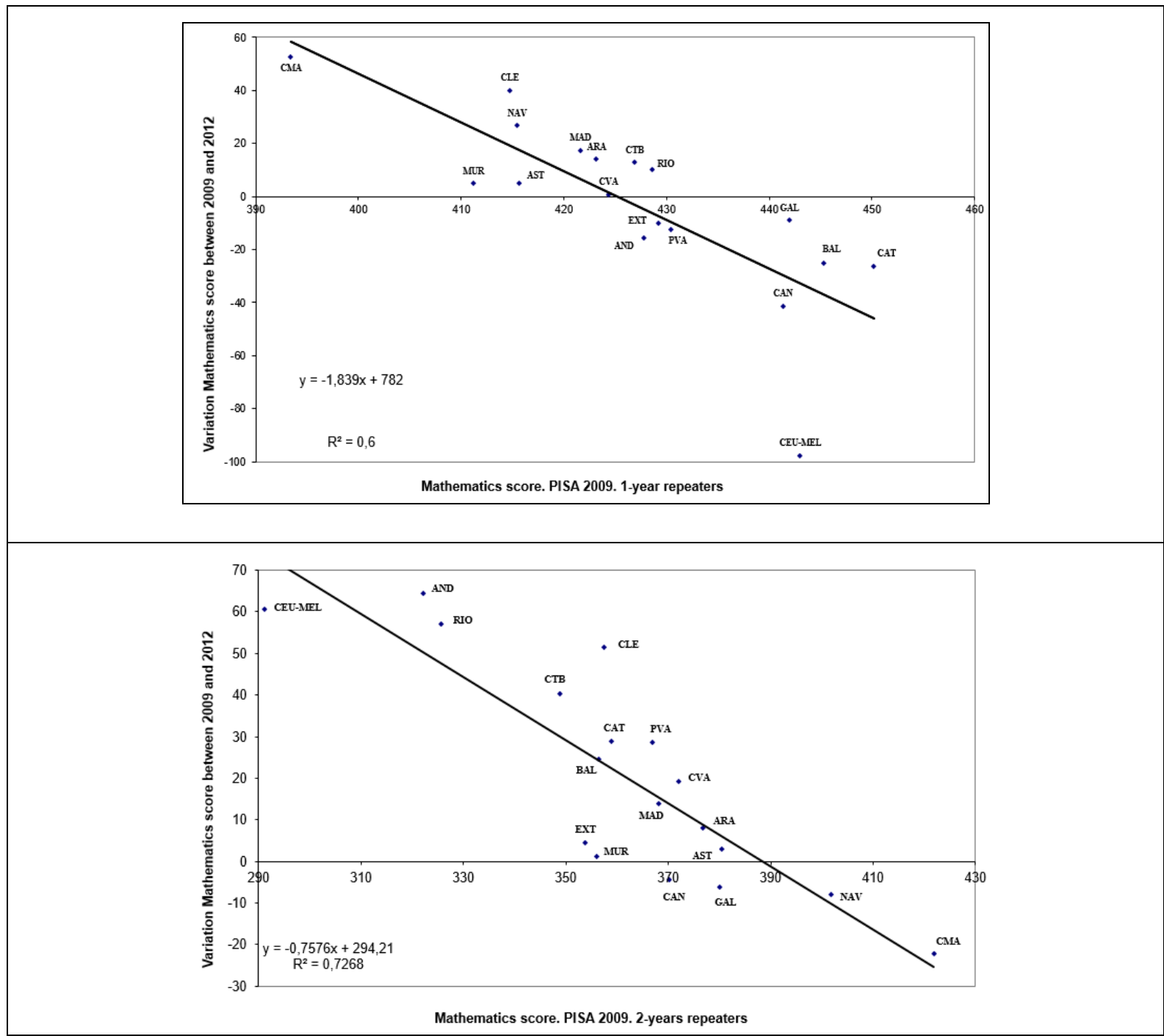

Figures 1 to 3. Relationship between PISA 2009 (Mathematics) and score growth rate between PISA 2009 and PISA 2012.

In the following, we offer the estimation results of the "difference-in-difference model". Tables 2 and 4 offer the results for the comparison between fully-participant and non-participant Communities. Tables 3 and 5 offer the results of the comparison between fully-participant and partial-participant Communities. Tables 2 and 4 offer the results for the comparison between PISA 2009 and 2012. Tables 3 and 5 offer the results for the comparison between PISA-ERA 2009 and PISA-CBA 2012.

\subsection{Comparison between Fully- Participant Communities and Non-Participant Communities in School 2.0}

For students who have repeated one or two years, we appreciate that the ratio computers per student has a negative and significant influence over Mathematics performance (-42.22 and -88.56 points, respectively). For non-repeater students, the availability of digital pad or notebook decreases Mathematics score corresponding to the CBA-module (-48.35 points for full-participant Communities and -23.26 points for nonparticipant Communities).

It seems that participation in the program School 2.0 has not lead to better results in the module of "Computer Based Assessment (CBA)". Among non-repeater students, the resource of ICT for doing homework (1-2 times per week) has exerted a negative effect in fully-participant Communities (-3.15 points), but a positive one in non-participant Communities (+55.62 points). For 2-years repeater students, we appreciate a negative and significant effect of ICT for doing homework over Mathematics performance (54.68 in non-participant Communities and -74.73 in fully-participant Communities). 


\subsection{Comparison between Fully-Participant Communities and Partial Participant Communities in School 2.0}

More computers per student increases Mathematics scores for non-repeater students of partial participant Communities (21.83 points), but for non-repeater students of participant Communities the effect is almost cancelled (due to the negative interaction term: -22.58 points). The availability of digital pad or notebook at school decreases Mathematics score by 13 points for repeater students of both fully-participants and partialparticipants Communities. For non-repeater students, we appreciate a negative effect $(-12.03)$ for fullyparticipant Communities

Regarding the module CBA, we observe that using ICT for doing homework (1-2 times per week) generates opposite effects between repeaters and non-repeaters. Non-repeater students who use ICT for homework (1-2 times per week) experiment an increase in Mathematics score by 39.02 points in fully-participant Communities (91.76 in partial participant Communities). For students who have repeated two years, there is an abrupt decrease in Mathematics score (-45.83 for fully-participants and -79.79 in partial-participant Communities).

Table 2 Difference-in-difference regression comparing fully-participant and no -participant Communities (PISA 2009 and PISA 2012) All public schools

\begin{tabular}{|c|c|c|c|c|c|c|}
\hline & \multicolumn{2}{|c|}{$\begin{array}{l}\text { No repeater } \\
\text { REP }(0)\end{array}$} & \multicolumn{2}{|c|}{$\begin{array}{c}\text { Repeated } 1 \text { year } \\
\operatorname{REP}(1,0) \text { or } \\
\operatorname{REP}(0,1)\end{array}$} & \multicolumn{2}{|c|}{$\begin{array}{c}\text { Repeated } 2 \text { years } \\
\operatorname{REP}(1,1) \text { or } \\
\operatorname{REP}(0,2)\end{array}$} \\
\hline & Coef & $t$ & Coef & $t$ & Coef & $t$ \\
\hline Computers per student (PISA 2012) & -114.17 & -5.19 & -42.22 & 7.78 & -88.56 & -1.60 \\
\hline $\begin{array}{l}\text { Growth rate of computers per student 2007- } \\
2012\end{array}$ & 1.56 & 3.12 & 0.64 & 1.06 & 0.96 & 0.96 \\
\hline Has notebook/digital pad in school & -7.96 & -3.42 & -16.78 & -6.91 & -21.91 & -4.63 \\
\hline Has participated in School 2.0 & -5.36 & -1.49 & 4.82 & 0.92 & 0.24 & 0.04 \\
\hline Year 2012 & -14.58 & -1.73 & -1.87 & -0.18 & 43.90 & 3.66 \\
\hline \multicolumn{7}{|l|}{ Interaction with participation in School 2.0: } \\
\hline Computers per student (PISA 2012) & 112.93 & 5.02 & 43.87 & 1.21 & 80.36 & 1.44 \\
\hline Notebook/digital pad in school & -6.66 & -2.44 & 4.84 & 1.28 & 10.89 & 1.66 \\
\hline Year 2012 & -5.78 & -0.58 & -34.65 & -3.68 & -26.95 & -1.65 \\
\hline $\begin{array}{l}\text { Growth rate of computers per student } \\
2007-2012\end{array}$ & -1.63 & -3.25 & -0.53 & -0.88 & -0.59 & -0.58 \\
\hline GDP per capita & 0.0004 & 1.80 & 0.0011 & 4.01 & 0.0007 & 1.39 \\
\hline Constant & 452.60 & 64.93 & 394.26 & 31.42 & 299.86 & 20.32 \\
\hline $\mathrm{N}$ & 14,200 & & 6,102 & & 1,762 & \\
\hline $\mathrm{R}^{2}$ & 0.5434 & & 0.5927 & & 0.5571 & \\
\hline
\end{tabular}

In all regressions we have used as explanatory variables: student nationality, age when arrived at Spain (for immigrant students), language spoken at home, immigrant mother/father, lives with only one parent, minutes per week devoted to Mathematics at home, having more than 100 books at home, level of education of mother/father, relation with economic activity of mother/father, size of municipality, class size, proportion of girls, proportion of immigrant students. Estimated coefficients are the average of the obtained coefficients for the 5 plausible values and using sample weights.

Fully-participants: Andalucía, Aragón, Cantabria, C. León, C. Mancha, Cataluña, Extremadura, Galicia, Navarra, Rioja, País Vasco, Ceuta y Melilla.

Non-participants: Madrid, Murcia, Comunidad Valenciana

Table 3 Difference-in-difference regression comparing fully-participant and partial-participant Communities (PISA 2009 and PISA 2012) All public schools

\begin{tabular}{|c|c|c|c|c|c|c|}
\hline & \multicolumn{2}{|c|}{$\begin{array}{l}\text { No repeater } \\
\operatorname{REP}(0)\end{array}$} & \multicolumn{2}{|c|}{$\begin{array}{l}\text { Repeated } 1 \text { year } \\
\operatorname{REP}(1,0) \text { or } \\
\operatorname{REP}(0,1)\end{array}$} & \multicolumn{2}{|c|}{$\begin{array}{c}\text { Repeated } 2 \text { years } \\
\operatorname{REP}(1,1) \text { or } \\
\operatorname{REP}(0,2)\end{array}$} \\
\hline & Coef & $\mathbf{t}$ & Coef & t & Coef & 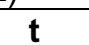 \\
\hline Computers per student (PISA 2012) & 21.83 & 1.72 & 19.56 & 1.55 & 24.25 & 1.05 \\
\hline $\begin{array}{l}\text { Growth rate of computers per student } \\
2007-2012\end{array}$ & -0.39 & -2.98 & -0.44 & -2.13 & -0.91 & -3.23 \\
\hline Has notebook/digital pad in school & -2.16 & -0.98 & -13.44 & -5.46 & -13.73 & -2.61 \\
\hline
\end{tabular}


Proceedings of INTCESS 2021 8th International Conference on Education and Education of Social Sciences 18-19 January, 2021

\begin{tabular}{|c|c|c|c|c|c|c|}
\hline Has participated in School 2.0 & -1.98 & -0.59 & -3.39 & -0.82 & 2.23 & 0.28 \\
\hline Year 2012 & -41.09 & -5.09 & -18.02 & -2.24 & 27.15 & 2.04 \\
\hline \multicolumn{7}{|l|}{$\begin{array}{l}\text { Interaction with participation in School } \\
2.0 \text { : }\end{array}$} \\
\hline Computers per student (PISA 2012) & -22.58 & -1.67 & -18.36 & -1.37 & -35.09 & -1.51 \\
\hline Notebook/digital pad in school & -12.03 & -4.39 & 2.03 & 0.54 & 4.80 & 0.65 \\
\hline Year 2012 & 14.04 & 1.38 & -10.64 & -1.09 & -27.79 & -1.50 \\
\hline $\begin{array}{l}\text { Growth rate of computers per } \\
\text { student 2007-2012 }\end{array}$ & 0.31 & 1.97 & 0.55 & 2.46 & 1.35 & 4.43 \\
\hline GDP per capita & 0.0004 & 1.92 & 0.0012 & 4.03 & 0.0011 & 2.23 \\
\hline Constant & 462.96 & 59.52 & 387.13 & 30.96 & 302.47 & 18.07 \\
\hline $\mathrm{N}$ & 14,735 & & 6,171 & & 1,727 & \\
\hline $\mathrm{R}^{2}$ & 0.6481 & & 0.5853 & & 0.6258 & \\
\hline
\end{tabular}

Fully-participants: Andalucía, Aragón, Cantabria, C. León, C. Mancha, Cataluña, Extremadura, Galicia, Navarra, Rioja, País Vasco, Ceuta y Melilla.

\section{Partial-participatns: Asturias, Baleares, Canarias}

Table 4. Difference-in-difference regression comparing fully-participant and no-participant Communities (PISA-ERA 2009 and PISA-CBA 2012) All public schools

\begin{tabular}{|c|c|c|c|c|c|c|}
\hline & \multicolumn{2}{|c|}{$\begin{array}{l}\text { No repeater } \\
\text { REP }(0)\end{array}$} & \multicolumn{2}{|c|}{$\begin{array}{c}\text { Repeated } 1 \text { year } \\
\operatorname{REP}(1,0) \text { or } \\
\operatorname{REP}(0,1)\end{array}$} & \multicolumn{2}{|c|}{$\begin{array}{c}\text { Repeated } 2 \text { years } \\
\operatorname{REP}(1,1) \text { or } \\
\operatorname{REP}(0,2)\end{array}$} \\
\hline & Coef & $t$ & Coef & $\mathbf{t}$ & Coef & $\mathbf{t}$ \\
\hline Computers per student (PISA 2012) & 0.00 & -0.04 & 0.01 & 0.60 & -0.01 & -0.16 \\
\hline $\begin{array}{l}\text { Growth rate of computers per student 2007- } \\
2012\end{array}$ & -0.33 & -0.96 & -0.96 & -2.74 & -0.11 & -0.13 \\
\hline $\begin{array}{l}\text { Has notebook/digital pad in school } \\
\text { Uses ICT for doing homework }\end{array}$ & -23.36 & -1.72 & 3.59 & 0.18 & -27.77 & -1.25 \\
\hline 1-2 times per month & 7.20 & 0.48 & 21.83 & 1.35 & -12.91 & -0.88 \\
\hline 1-2 times per week & 55.62 & 4.66 & -0.19 & -0.01 & -54.68 & -3.40 \\
\hline Almost all days & 5.67 & 0.36 & 0.15 & 0.01 & -20.42 & -1.09 \\
\hline Has participated in School 2.0 & -58.77 & -2.45 & -15.45 & -0.60 & -124.83 & -4.14 \\
\hline Year 2012 & -90.23 & -4.52 & -24.37 & -1.06 & -151.42 & -3.19 \\
\hline Interaction with participation in School 2.0: & & & & & & \\
\hline Computers per student (PISA 2012) & $\begin{array}{l}21.55 \\
3378\end{array}$ & 1.02 & 1.54 & 0.12 & 13.42 & 0.72 \\
\hline $\begin{array}{l}\text { Notebook/digital pad in school } \\
\text { Year } 2012\end{array}$ & $\begin{array}{l}33.78 \\
81.00\end{array}$ & $\begin{array}{l}1.78 \\
1.72\end{array}$ & $\begin{array}{r}-30.54 \\
-6.67\end{array}$ & $\begin{array}{l}-1.63 \\
-0.20\end{array}$ & $\begin{array}{r}35.78 \\
136.24\end{array}$ & $\begin{array}{l}1.59 \\
1.57\end{array}$ \\
\hline $\begin{array}{l}\text { Growth rate of computers per student } \\
2007-2012\end{array}$ & 0.36 & 0.67 & 0.86 & 2.12 & 0.27 & 0.27 \\
\hline ICT for homework: $1-2$ times/month & 33.74 & 2.48 & 24.65 & 1.37 & 31.51 & 1.44 \\
\hline ICT for homework: 1-2 times/week & -14.20 & -1.19 & 7.79 & 0.37 & 104.78 & 5.15 \\
\hline ICT for homework: almost all days & 34.84 & 1.65 & 19.14 & 0.85 & 56.33 & 1.72 \\
\hline GDP per capita & -0.0030 & -2.09 & -0.001 & -0.98 & -0.0026 & -1.04 \\
\hline Constant & 505.76 & 13.66 & 414.98 & 10.23 & 535.49 & 9.69 \\
\hline $\begin{array}{l}\mathrm{N} \\
\mathrm{R}^{2}\end{array}$ & $\begin{array}{r}4,458 \\
0.7700\end{array}$ & & $\begin{array}{r}1,521 \\
0.8092\end{array}$ & & $\begin{array}{r}459 \\
0.7334\end{array}$ & \\
\hline
\end{tabular}

Fully-participants: Andalucía, Aragón, Cantabria, C. León, C. Mancha, Cataluña, Extremadura, Galicia, Navarra, Rioja, País Vasco, Ceuta y Melilla.

Non-participants: Madrid, Murcia, Comunidad Valenciana

Table 5 Difference-in-difference regression comparing fully-participant and partial-participant Communities (PISA-ERA 2009 and PISA-CBA 2012) All public schools

\begin{tabular}{|c|c|c|c|c|c|c|}
\hline & \multicolumn{2}{|c|}{$\begin{array}{l}\text { No repeater } \\
R E P(0)\end{array}$} & \multicolumn{2}{|c|}{$\begin{array}{c}\text { Repeated } 1 \text { year } \\
\operatorname{REP}(1,0) \text { or } \\
\operatorname{REP}(0,1)\end{array}$} & \multicolumn{2}{|c|}{$\begin{array}{c}\text { Repeated } 2 \text { years } \\
\operatorname{REP}(1,1) \text { or } \\
\operatorname{REP}(0,2)\end{array}$} \\
\hline & Coef & $\mathbf{t}$ & Coef & $\mathbf{t}$ & Coef & $\mathbf{t}$ \\
\hline Computers per student (PISA 2012) & 0.00 & 0.14 & 0.01 & 0.57 & -0.04 & -1.02 \\
\hline $\begin{array}{l}\text { Growth rate of computers per student 2007- } \\
2012\end{array}$ & -2.24 & -2.82 & 0.02 & 0.03 & 3.35 & 2.18 \\
\hline
\end{tabular}


Proceedings of INTCESS 2021 8th International Conference on Education and Education of Social Sciences 18-19 January, 2021

\begin{tabular}{|c|c|c|c|c|c|c|}
\hline Has notebook/digital pad in school & -14.28 & -1.51 & 13.76 & 1.13 & -13.97 & -0.39 \\
\hline \multicolumn{7}{|l|}{ Uses ICT for doing homework } \\
\hline 1-2 times per month & 91.17 & 4.62 & 44.21 & 1.99 & 21.79 & 0.48 \\
\hline 1-2 times per week & 91.76 & 5.35 & 15.93 & 0.98 & -79.79 & -2.11 \\
\hline Almost all days & 68.61 & 3.38 & 11.46 & 0.64 & -31.87 & -0.67 \\
\hline Has participated in School 2.0 & 5.92 & 0.35 & 7.58 & 0.56 & -115.17 & -2.98 \\
\hline Year 2012 & 24.15 & 1.00 & -53.45 & -1.30 & -158.16 & -2.05 \\
\hline \multicolumn{7}{|l|}{ Interaction with participation in School 2.0: } \\
\hline Computers per student (PISA 2012) & 22.60 & 1.12 & 3.54 & 0.26 & 5.78 & 0.25 \\
\hline Notebook/digital pad in school & 25.97 & 1.82 & -41.33 & -2.26 & 23.03 & 0.70 \\
\hline Year 2012 & -18.35 & -0.42 & 22.48 & 0.49 & 197.45 & 2.24 \\
\hline $\begin{array}{l}\text { Growth rate of computers per student } \\
2007-2012\end{array}$ & 2.19 & 2.71 & -0.11 & -0.13 & -2.78 & -1.94 \\
\hline ICT for homework: 1-2 times/month & -52.74 & -2.52 & 5.05 & 0.21 & 2.63 & 0.05 \\
\hline ICT for homework: 1-2 times/week & -49.91 & -2.46 & -8.36 & -0.60 & 149.13 & 3.72 \\
\hline ICT for homework: almost all days & -35.76 & -2.02 & 4.47 & 0.23 & 113.99 & 2.47 \\
\hline GDP per capita & -0.0030 & -2.05 & -0.001 & -0.79 & -0.0031 & -1.14 \\
\hline Constant & 472.74 & 16.91 & 371.31 & 14.82 & 407.65 & 6.09 \\
\hline $\mathrm{N}$ & 4,232 & & 1,402 & & 411 & \\
\hline $\mathrm{R}^{2}$ & 0.7580 & & 0.8261 & & 0.8232 & \\
\hline
\end{tabular}

Fully-participants: Andalucía, Aragón, Cantabria, C. León, C. Mancha, Cataluña, Extremadura, Galicia, Navarra, Rioja, País Vasco, Ceuta y Melilla.

Partial-participatns: Asturias, Baleares, Canarias

\subsection{Positive Spillovers}

Apart from the effect of the program School 2.0 over academic results, we are also concerned with other types of effects, such as spillover effects. It is interesting to determine if this program has affected the ways in which students interact among them (talk about Mathematics, join together to solve problems, exchange information regarding different issues of the subject). For this purpose, we have used the question "talk about Mathematics with classmates or friends" and have estimated an ordered probit for the posible answers (never, sometimes, often, almost always). We appreciate a significant and positive effect for students of participant Communities. The probability for the event "talk about mathematics often or almost always" increases by $36 \%$ for non-repeaters and by $110 \%$ for repeater students of participant Communities (as compared to non-participants).

On the other hand, the probability of "helping other classmates or friends with Mathematics" increases by $89 \%$ for repeater students of participant Communities as compared to non-participants (there are not significant effects for non-repeater students).

\section{CONCLUSIONS}

Preliminary results do not offer favorable effects of the program Schools 2.0 over Mathematics achievement. In general lines, our results go in line with those of [10], who observed that the employment of ICT as a substitution of traditional teaching methods, lead to worse academic results. However, there was a reduced but positive effect when ICT were used as a complement. For future research, we want to concentrate in the subset of participant Communities and analyze in detail how student's achievement has reacted to the implementation of the program School 2.0. We would like to determine if certain characteristics such as the adaptation of curricular contents, the combination of books with notebooks or the type of Mathematics exercises performed during classes could make a difference among participant Communities.

\section{REFERENCE LIST}

[1] Machin, S., McNally, S., Silva, O. (2007). New technology in schools: is there a payoff? Economic Journal 117, 1145-1167.

[2] Banerjee, A., Cole, S., Duflo, E., Linden, L. (2004). Remedying education: evidence from two randomized experiments in India. Quarterly Journal of Economics 122(3), 1235-1264. 
[3] Barrow, L., Nmarkman, L., Rouse, C. (2009). Technology's edge: the educational benefits of computer-aided instruction. American Economic Journal: Economic Policy 1(1), 52-74.

[4] Carrillo, P., Onofa, M., Ponce, J. (2010). Information technology and student achievement: evidence from a randomized experiment in Ecuador. Inter-American Development Bank Working Paper Series No. 223.

[5] Golsbee, A., Guryan, J. (2002). The impact of internet subsidies on public schools. NBER Working Paper No. 9090.

[6] Angrist, J., Lavy, V. (2002). New evidence on classroom computers and pupil learning. Economic Journal 112, 735-765.

[7] Leuven E., Lindahl, M., Oosterbeek, H., Webbink, D. (2004). The effect of extra funding for disadvantaged pupils on achievement. IZA Discussion Paper No. 1122.

[8] Brynjolfsson, E., Hitt, L. M. (2000). Beyond computation: information technology, organizational transformation and business performance. Journal of Economic Perspectives 14(4), 23-48.

[9] OCDE (2009). PISA Data analysis manual: SPSS. 2nd Edition. OCDE.

[10] Linden, L. (2008). Complement or substitute? The effect of technology on student achievement in India. InfoDev Working Paper no. 17. Washington, DC: World Bank 